\title{
Application of DNA markers linked to the potato $H 1$ gene conferring resistance to pathotype Ro1 of Globodera rostochiensis
}

\author{
Renata Galek • Michał Rurek • Walter S. De Jong • \\ Grzegorz Pietkiewicz • Halina Augustyniak • \\ Ewa Sawicka-Sienkiewicz
}

Received: 16 March 2011 /Revised: 20 April 2011 / Accepted: 30 April 2011 /Published online: 11 May 2011

(C) The Author(s) 2011. This article is published with open access at Springerlink.com

\begin{abstract}
Ninety-one potato genotypes (cultivars and breeding lines) selected as resistant or susceptible to pathotype Rol of Globodera rostochiensis were screened for the presence of two PCR markers, 0.14 and $0.76 \mathrm{~kb}$ in length. Both PCR markers were linked with the $H 1$ gene, located at the distal end of the long arm of chromosome $\mathrm{V}$, and were present in 88 to $100 \%$ of the resistant cultivars and breeding lines. The $0.76 \mathrm{~kb}$ PCR marker was detected in all resistant genotypes and in approximately $86 \%$ of susceptible breeding lines as well as in all susceptible cultivars. The $0.14 \mathrm{~kb}$ marker was detected in $88 \%$ of resistant breeding lines and in $94 \%$ of resistant cultivars. Most of the susceptible genotypes tested (91\% of cultivars, but only $50 \%$ of breeding lines) did not show the presence of the $0.14 \mathrm{~kb}$ marker. We conclude that the $0.14 \mathrm{kbH} 1$ marker is likely to be useful for the proper
\end{abstract}

Renata Galek and Michał Rurek contributed equally to the work

R. Galek • E. Sawicka-Sienkiewicz

Department of Genetics, Plant Breeding and Seed Production,

Faculty of Life Sciences and Technology,

Wroclaw University of Environmental and Life Sciences,

Plac Grunwaldzki 24a,

53-363, Wroclaw, Poland

M. Rurek $(\bowtie) \cdot$ G. Pietkiewicz $\cdot$ H. Augustyniak Department of Molecular and Cellular Biology, Institute of Molecular Biology and Biotechnology,

Faculty of Biology, Adam Mickiewicz University,

Umultowska 89,

61-614, Poznan, Poland

e-mail: rurek@amu.edu.pl

W. S. De Jong

Department of Plant Breeding and Genetics, Cornell University,

Ithaca, NY 14850, USA selection of potato genotypes resistant to the Rol pathotype of G. rostochiensis.

Keywords Globodera rostochiensis · Marker Pathotype Ro1 PCR

The discovery of resistance genes against potato cyst nematodes (Globodera rostochiensis, golden cyst nematode, and G. pallida, white cyst nematode) in Solanum tuberosum ssp. andigena, S. spegazzinii and S. vernei, and their subsequent incorporation by breeders into many potato cultivars is one of the most important achievements in European potato breeding. Since 2006 resistance to $G$. rostochiensis has been obligatory for new potato cultivars in Poland. Genetic mapping of resistance loci in potato is generally performed at the diploid level, but considerable progress has also been made in tetraploid genotypes. To date (Finkers-Tomczak et al. 2011) 14 potato cyst nematode resistance gene loci have been mapped on eight linkage groups in potato. Four resistance genes (H1, GroVI, Grol and $G p a 2$ ) are responsible for nearly absolute resistance to one or more nematode pathotypes, while other genes confer only partial resistance (Bakker et al. 2004). The inheritance of nematode resistance ranges from dominant monogenic to polygenic alleles; it depends on the pathogen and the source of resistance. The genes $H 1$ and Grol, conferring resistance to the potato cyst nematode $G$. rostochiensis, were localised on potato chromosome V and VII, respectively (Barone et al. 1990; Gebhardt et al. 1993). Those sources of resistance, are effective against all the major pathotypes of $G$. rostochiensis. Grol is inherited as a single dominant allele conferring resistance to the $G$. rostochiensis pathotypes Ro1 and Ro5. The monogenic $H 1$ locus from $S$. tuberosum ssp. andigena is associated with resistance to the $G$. rostochiensis pathotype Ro1 and Ro4. The inheritance of Ro1 resistance from $S$. 
spegazzinii and $S$. vernei is complex and based on several loci (Jacobs et al. 1996).

The aim of our study was to evaluate the usefulness of two PCR based markers linked to $H 1$ for rapid screening of Polish potato genotypes (cultivars and breeding lines) for resistance to $G$. rostochiensis. The potato cultivars and breeding lines originated from Polish Plant Breeding Stations (Strzekęcin, Krokowa and Dybowo) and were propagated in Swojec (Experimental Station of the University of Environmental and Life Sciences in Wroclaw, Poland). The plants were grown in the field and young leaves were taken for DNA analyses. The biological test for resistance to G. rostochiensis pathotype Ro1 was conducted for 3 years, according to the protocol of Stefan and Malinowska (2000). Plants with less than 3 cysts were considered as resistant (R) and those showing more than 3 cysts as susceptible (S). Plant DNA was extracted from flash-frozen leaves, using Jughans and Metzlaff (1990) or DNA Plant MiniKit (Qiagen) protocols. For PCR detection of markers linked to the dominant allele of $H 1$, two pairs of primers were used. A product of $0.76 \mathrm{~kb}$ resulted from amplification with primers $\mathrm{F}\left(5^{\prime}-\right.$ GGCGTTACAGTCGCCGTAT-3') and R (5'-GTTGA AGAAATATGGAATCAAA-3'), while primers TG689AlleleSpecific (5'-TAAAACTCTTGGTTATAGCCTAT-3') and TG689indel12 (5'-CAATAGAATGTGTTGTTTCAC CAA-3') amplified a $0.14 \mathrm{~kb}$ product. The conditions for PCR amplification with $F$ and $R$ primers, according to Niewöhner et al. (1995) and modified by Skupinová et al. (2002) were as follows: $6 \mathrm{ng}$ total DNA, $0.05 \mathrm{U}$ of Taq Platinum polymerase, $0.25 \mathrm{mM} \mathrm{dNTPs}$ and $1 \mathrm{x}$ Taq Platinum polymerase buffer containing $2 \mathrm{mM} \mathrm{MgCl}_{2}$ in $25 \mu \mathrm{l}$ total volume with $0.1 \mu \mathrm{M}$ of each primer. The thermal profile was as follows: $96^{\circ} \mathrm{C}-3 \mathrm{~min}$., next 45 cycles of $93^{\circ} \mathrm{C}-30 \mathrm{~s}, 51^{\circ} \mathrm{C}-45 \mathrm{~s}$ and $72^{\circ} \mathrm{C}-90 \mathrm{~s}$. The last step included $72^{\circ} \mathrm{C}-90 \mathrm{~s}$. The conditions for PCR amplification of $H 1$ allele with TG689AlleleSpecific and TG689indel12 primers (as well as amplification of a $0.29 \mathrm{~kb}$ control fragment with primers designed against conserved regions of beta carotene hydroxylase: BCH-F2 [5'-CATGACA TAGTTTGAATTTTGAGTC-3'] and BCH-R2 [5'GCTTTGGCGCTGCCGTAAGTT-3'] (Brown et al. 2006)) were as follows: $12 \mathrm{ng}$ total DNA, $0.06 \mathrm{U}$ of Taq Platinum polymerase, $0.25 \mathrm{mM}$ dNTPs, $0.2 \mu \mathrm{M}$ of each primer (except BCH primers- $0.08 \mu \mathrm{M}$ ) and $1 \mathrm{x}$ Taq Platinum polymerase buffer containing $3 \mathrm{mM} \mathrm{MgCl} 2$ in $25 \mu$ total volume. The thermal profile was as follows: $96^{\circ} \mathrm{C}-3 \mathrm{~min}$., next 50 cycles of $93^{\circ} \mathrm{C}-70 \mathrm{~s}, 51^{\circ} \mathrm{C}-60 \mathrm{~s}$ and $72^{\circ} \mathrm{C}-90 \mathrm{~s}$. Final elongation proceeded for $90 \mathrm{~s}$ at $72^{\circ} \mathrm{C}$. All the PCR analyses were performed in two independent labs on Hybaid and Biometra thermocyclers. Because PCR is very sensitive to many factors, to rule out the possibility of failed PCR reactions, all assays (from at least three biological replicates) were performed in at least three technical replicates in this study. Amplification products were separated on $2 \%$ agarose gels and stained with ethidium bromide.

The results obtained with PCR markers developed for the $H 1$ locus (Niewöhner et al. 1995) are presented in Fig. 1 and in Table 1. Genotypes presented in Table 1 were chosen randomly. The $0.76 \mathrm{~kb}$ PCR marker was detected in all resistant genotypes and in approximately $86 \%$ of susceptible breeding lines as well as in all susceptible cultivars (Table 1). According to Skupinová et al. (2002) this marker detects only dominant $H 1$ allele in potato genotypes. Thus, this marker is not well-suited for fast resistance screening of Polish potato germplasm. The $0.14 \mathrm{~kb}$ PCR marker appeared much more useful. We found a positive, but not perfect, relationship between the presence of the $141 \mathrm{bp}$ PCR marker and resistance to the Ro1 pathotype estimated phenotypically by biological tests. Eighty eight percent of resistant breeding lines and $94 \%$ of resistant cultivars tested displayed the presence of the $0.14 \mathrm{~kb}$ marker. Most of the susceptible genotypes tested (91\% of cultivars, but only $50 \%$ of breeding lines) did not show the presence of the $0.14 \mathrm{~kb}$ marker (Table 1).

Experiments performed with molecular markers mapping system by Kreike et al. (1993) indicated that resistance to the pathotype Ro1 is not determined by a

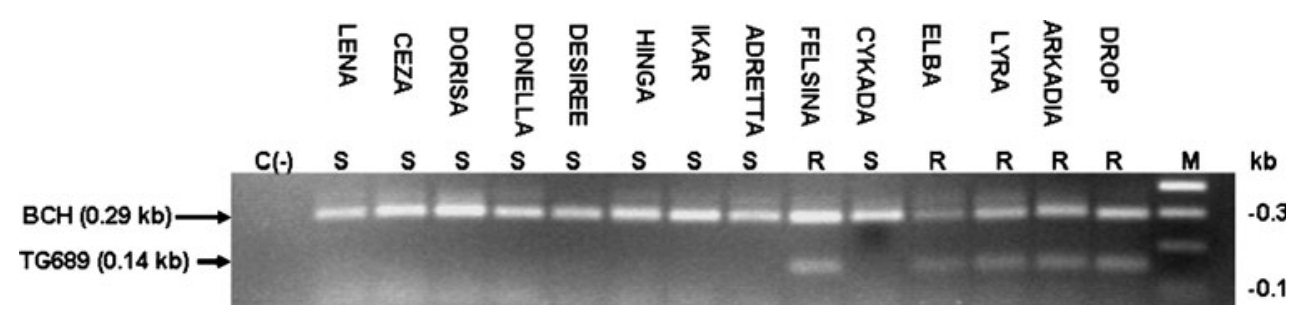

Fig. 1 Electrophoretical pattern (on 2\% agarose gel) of analysed $0.14 \mathrm{~kb}$ marker (amplified with TG689 primers) for different potato genotypes. Amplification of a fragment of the beta carotene hydroxylase gene with $\mathrm{BCH}$ primers (giving $0.29 \mathrm{~kb}$ PCR product) served as a positive control for all PCR reactions, confirming the quality of isolated total DNA samples. R - resistant genotypes; $\mathrm{S}$ susceptible genotypes; $\mathrm{C}(-)$ - negative control (containing $\mathrm{H}_{2} \mathrm{O}$ instead of DNA); M- DNA molecular weight marker. The size of DNA fragments is indicated in $\mathrm{kb}$ 


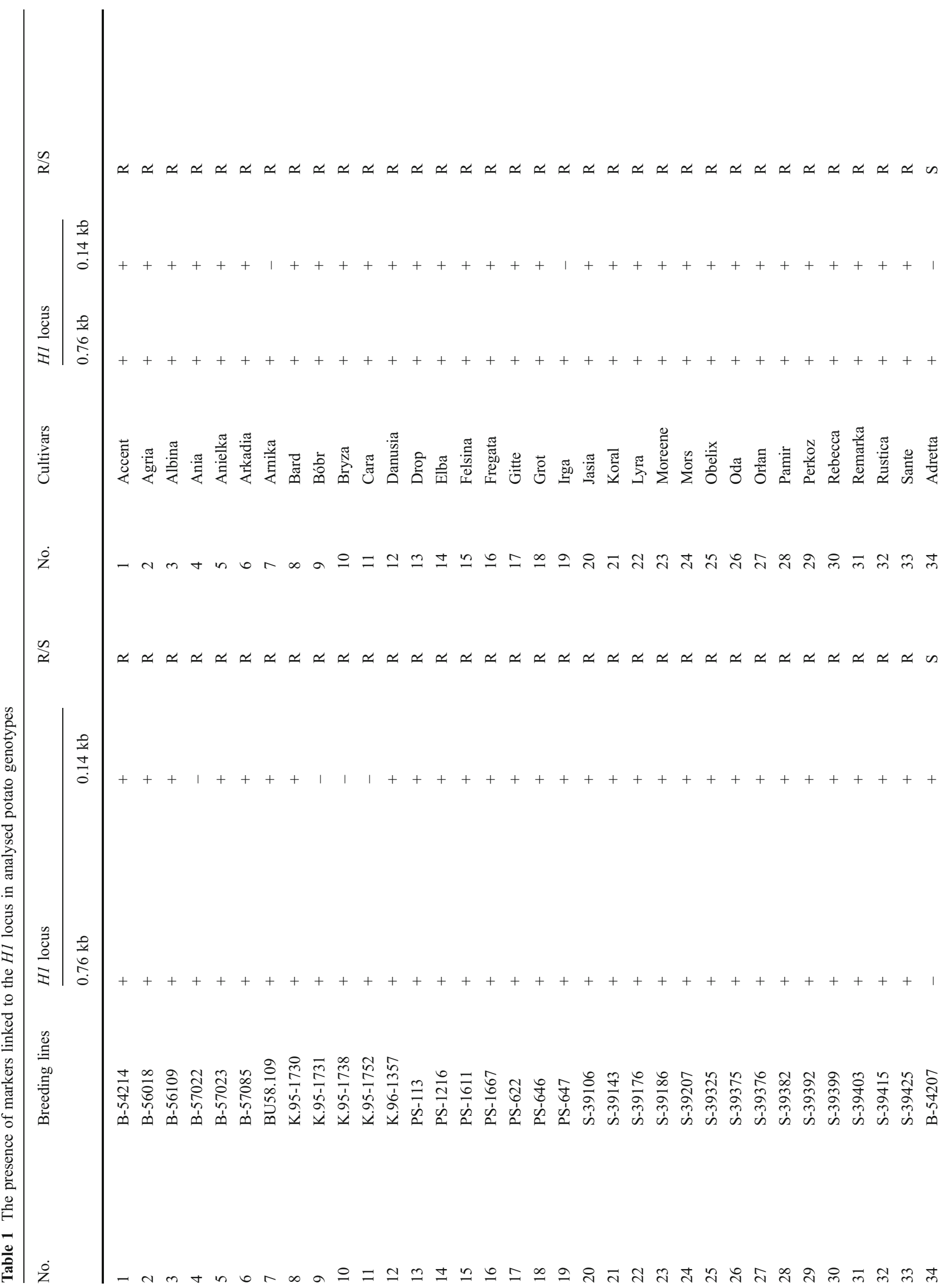


410

J Appl Genetics (2011) 52:407-411

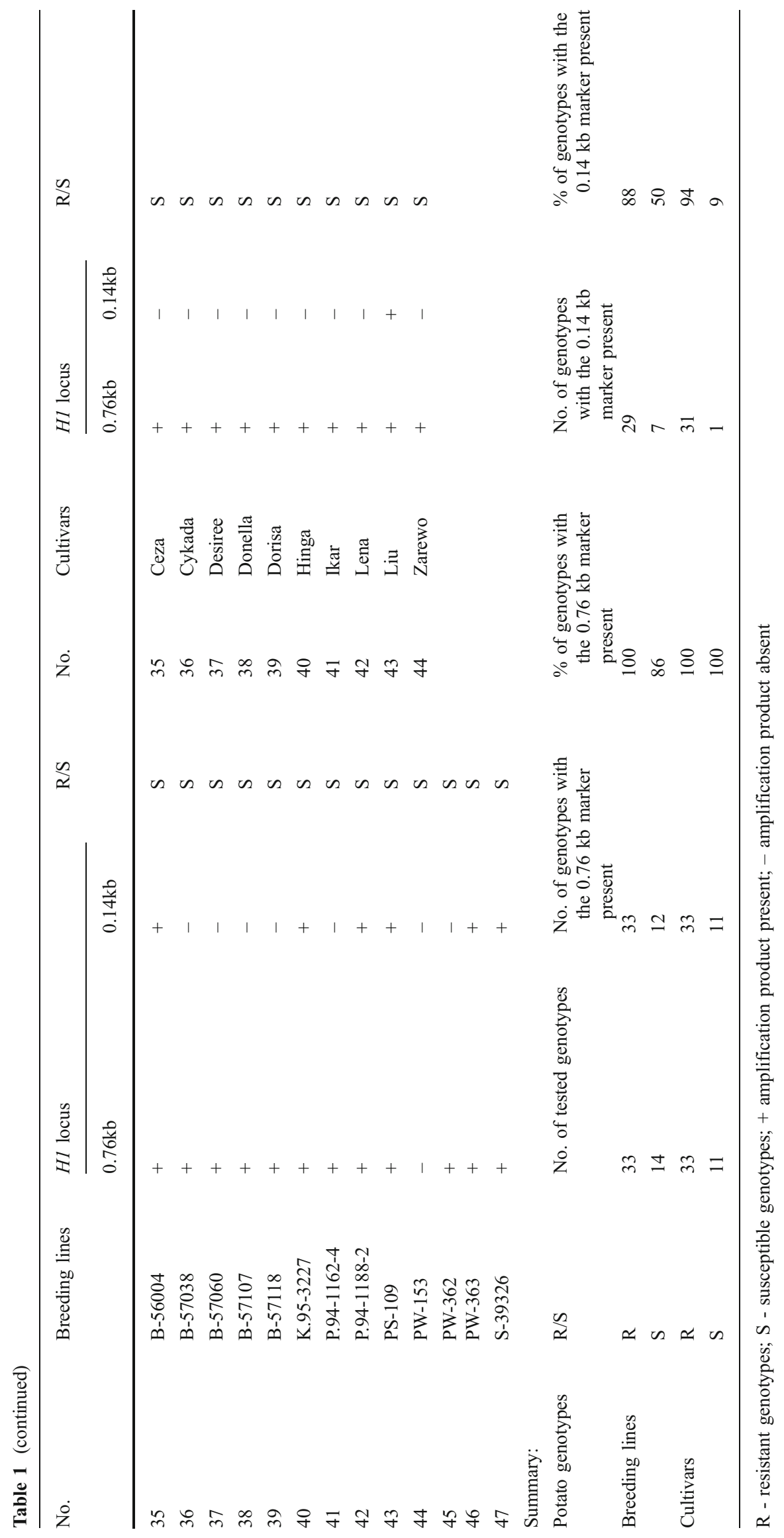

Springer 
single locus, which is localised in chromosomes V or VII; it is rather a quantitative polygenic way of inheritance. Because tetraploid potatoes can carry resistance genes from many sources it can be difficult to use markers that reliably distinguish resistant and susceptible genotypes. Nevertheless, PCR-based methods using primers may be promising among many other approaches in those efforts (Leister et al. 1996). A potato genotype may be resistant to pathotype Ro1, for example, even though it does not contain the $H 1$ gene, for instance, by having resistance derived from $S$. spegazzinii (Kreike et al. 1993). In addition, markers like the $0.14 \mathrm{~kb}$ one described here can become separated from resistance by recombination. Therefore, bioassays are the only way to prove that potato markers represent resistance to the golden cyst nematode $G$. rostochiensis.

The conclusion emerging from our study would be the following. For breeders working with many different genotypes and multiple sources of resistance, using markers linked to $H 1$ provide the opportunity to track $H 1$ independently of any other resistance genes that might also be present, e.g. pyramiding resistance genes. In practice it may prove useful to test for the presence of $H 1$ markers before using bioassays, as the marker is much simpler to deploy. This approach will take less time and give more reproducible results than starting with biological tests. Working to develop additional markers linked to $H 1$, as well as Gro1, may also prove productive.

Authors would like to thank breeders from Polish Plant Breeding Stations: Strzekęcin, Krokowa and Dybowo for providing us with the plant material and Bożena Zelent for the excellent technical assistance. This study was supported by the Polish Agricultural Property Agency (grants no. 41/H and P/SK 114) for 2001-2004.

All experiments carried out in this study complied with Polish law.

The authors declared that they have no conflict of interests.

Open Access This article is distributed under the terms of the Creative Commons Attribution Noncommercial License which permits any noncommercial use, distribution, and reproduction in any medium, provided the original author(s) and source are credited.

\section{References}

Bakker E, Achenbach U, Bakker J, van Vliet J, Peleman J, Segers B, van der Heijden S, van der Linde P, Graveland R, Hutten R, van Eck H, Coppoolse E, van der Vossen E, Bakker J, Goverse A (2004) A high-resolution map of the H1 locus harbouring resistance to the potato cyst nematode Globodera rostochiensis. Theor Appl Genet 109:146-152

Barone A, Ritter E, Schachtschabel U, Debener T, Salamini F, Gebhardt C (1990) Localisation of restriction fragment length polymorphism mapping in potato of a major dominant gene conferring resistance to the potato cyst nematode Globodera rostochiensis. Mol Gen Genet 224:177-182

Brown CR, Kim TS, Ganga Z, Haynes K, De Jong D, Jahn M, Paran I, De Jong W (2006) Segregation of total carotenoid in high level potato germplasm and its relationship to beta-carotene hydroxylase polymorphism. Am J Potato Res 83:365-372

Finkers-Tomczak A, Bakker E, de Boer J, van der Vossen E, Achenbach U, Golas T, Suryaningrat S, Smant G, Bakker J, Goverse A (2011) Comparative sequence analysis of the potato cyst nematode resistance locus $\mathrm{Hl}$ reveals a major lack of co-linearity between three haplotypes in potato (Solanum tuberosum ssp.). Theor Appl Genet 122:595-608

Gebhardt C, Mugniéry D, Ritter E, Salamini F, Bonel E (1993) Identification of RFLP markers closely linked to the $H 1$ gene conferring resistance to Globodera rostochiensis in potato. Theor Appl Genet 85:541-544

Jacobs JME, van Eck HJ, Horsman K, Arens PFP, Verkerk-Bakker B, Jacobson E, Pereira A, Stiekema W (1996) Mapping of resistance to the potato cyst nematode Globodera rostochiensis from wild potato species Solanum vernei. Mol Breed 2:51-60

Jughans H, Metzlaff M (1990) A simple and rapid method for the preparation of total plant DNA. Biotechniques 8:176

Kreike CM, de Koning JRA, Vinke JH, Van Ooijen JW, Gebhardt C, Stiekema WJ (1993) Mapping of loci involved in quantitatively inherited resistance to the potato cyst nematode Globodera rostochiensis pathotype Ro1. Theor Appl Genet 87:464-470

Leister D, Ballvora A, Salamini F, Gebhardt C (1996) A PCR-based approach for isolating pathogen resistance genes from potato with potential for wide application in plants. Nat Genet 14:421-429

Niewöhner J, Salamini F, Gebhardt C (1995) Development of PCR assays diagnostic for RFLP marker alleles closely linked to alleles Grol and H1, conferring resistance to the root cyst nematode Globodera rostochiensis in potato. Mol Breed 1:57-78

Skupinová S, Vejl P, Sedlák P, Domkářova J (2002) Segregation of DNA markers of potato (Solanum tuberosum ssp. tuberosum L.) resistant against Ro1 pathotype Globodera rostochiensis in selected F1 progeny. Rostlinná Výroba 45:480-485

Stefan K, Malinowska E (2000) Metodyka badania odporności materiałów hodowlanych ziemniaka na raka, matwika ziemniaczanego i mątwika agresywnego. Ziemniak Pol 1:26-30 